\title{
Testing the Effect of Smart Egg Puzzle Games on Understanding the Geometry Concepts of Early Childhood
}

\author{
Endang Puspitasari ${ }^{1, a}$ *, Siti Masitoh ${ }^{1, b} \&$ Miftakhul Jannah ${ }^{1, c}$ \\ Postgraduate of Basic Education, Surabaya State University, East Java, 60213, Indonesia \\ Jl. Rektorat unesa, Lidah Wetan Kecamatan Lakarsantri Surabaya, East Java, 60213, Indonesia \\ ${ }^{*}$ Corresponding Author: endang.17070855004@mhs.unesa.ac.id
}

How to Cite: Puspitasari, E., Masitoh, S., \& Jannah, M. (2019). Testing the Effect of Smart Egg Puzzle Games on Understanding the Geometry Concepts of Early Childhood. International Journal for Educational and Vocational Studies, 1(1), 68-71.

\section{ARTICLE HISTORY}

Received: 25 March 2019

Revised: 24 April 2019

Accepted: 29 May 2019

\section{KEYWORDS}

Smart egg puzzle game

Understanding the concept of geometry

Early childhood

\section{ABSTRACT}

This study aims to examine the effects of smart egg puzzle games on understanding the concepts of early childhood geometry. This study uses a type of quasi-experimental research with nonequivalent control group design, where a group of experiments and control groups was not randomly selected. The population in this study were all TK Aisyiyah branches in Ngagel Surabaya, totaling 237 children with a sample of 88 children. Data collection is done by participant observation to determine the understanding of the concept of child geometry. The data analysis technique used is parametric statistics by using one-way ANOVA for samples that correlate with each other. From the results of the analysis obtained $F_{\text {count }} \geq F_{\text {table }}(21.4 \geq 3.10)$, this egg puzzle game has a good effect on understanding geometric concepts.

\section{INTRODUCTION}

Early childhood education is a nurturing and fostering effort directed at children from the age of zero to the age of Six years which aims to help the growth and development of children so that children have the readiness to enter further education using providing educational stimuli. Child development in the future will be largely determined by various stimuli/meaningful stimuli given from an early age. Therefore early childhood education is the most important education. Encouragement or development efforts so that children can develop optimally more precisely can be done at the beginning of a child's life. Early age is a golden age to stimulate all aspects of development. This golden period only lasts one time throughout the life span. Therefore, at an early age, a comprehensive development effort is needed that involves aspects of care, health, education, and protection.

Lucas (2017) states that early childhood education is a stage with its own identity, where children get a series of lessons that will contribute to the development of children. According to Sugiono (2009: 7), Early childhood education is an educational process that is needed by early childhood to achieve all aspects of development. Early childhood can explain a difference, using symbols in his mind to inform the objects he saw or the events that occurred. This cognitive ability is often associated with mathematical, logical intelligence, which is the intelligence of children in understanding and mastering the concepts of numbers, addition, subtraction. Cognitive development is the same as intellectual because many intellectual processes relate to various concepts that children also have with children's thinking skills in solving problems. Sujiono (2009: 214) explains that cognitive development goals are directed at developing auditory, visual, tactic, kinesthetic, early science, arithmetic, and geometry.

Based on the reality in the field that the lack of understanding of geometric concepts, the factor is because the concept of geometry is rarely taught to children. The teacher, as the main focus and controller of learning, is done classically. Children only respond while the teacher is only as a media and visual aid. One of the teaching materials in school is geometry learning; by analyzing the characteristics of shapes, shapes, and structures, the child will understand geometry. Geometry thinking aspects are spatial visual abilities, building and having field and space knowledge. Problems found that some children lack an understanding of geometric concepts. This is shown when the child mentions and groups objects in the form of geometry, most children are still confused, doubtful, and mistaken. 
One strategy to stimulate children's cognitive development is playing, playing activities is a world of children that must be well directed and attractively packaged so that when learning activities are more fun. According to Clark (2018), the game serves the mastery of childhood, and the game helps children to master the conditions that occur that are related to influence, cognitive, language, and social. The type of play in the game is, of course, various, but in developing the ability to introduce geometry in children can be done with smart egg puzzle games. As stated by Beaty (2013: 240), puzzle games can train hand coordination and concentration done by matching the shape or connecting parts of the image as a whole.

The smart egg puzzle game is an existing game, which is adapted to the learning goals and characteristics of the child. Whether it is in terms of the form of the game, equipment, number of players, rules, and area of play. The reason for choosing smart egg puzzles in this game is because this game can train to understand children's geometry concepts. Through the activity of playing and assembling geometric shapes into a complete form, the child can know, understand and apply to daily activities by learning while recognizing geometry (triangles, circles, squares, rectangles) and children can interact with their friends during the game take place. The smart egg puzzle game is made of egg-shaped EVA foam. Geometry images contained in this puzzle are expected to make children happy and can stimulate understanding of the concept of child geometry. This egg puzzle measures $\pm 9 \mathrm{~cm}$ in radius and the obstacle area is $3 \mathrm{x} 1$ meters.

In the egg puzzle pieces, there are geometric shapes which include triangles, rectangles, circles and rectangles used to understand geometric concepts and drawings of surrounding objects such as farmer hats, wall clocks, whiteboards and handkerchiefs used to classify geometric shapes according to object. How to play this game with teams and pass several obstacles to pair the shape of the egg puzzle into a complete puzzle. This is so that children can work together with their peers in completing puzzle games. Smart egg puzzle games are designed in color to attract children's interest and can teach the understanding of geometric concepts in children in a way that is fun and does not make children bored.

\section{METHOD}

This study uses quantitative research methods with this type of research is a quasi-experiment with a non-equivalent control group design, where a group of experiments and control groups is not randomly selected. In conducting this experimental research, researchers divided the two groups, namely the experimental group and the control group, the two groups had the same characteristics and characteristics. In the experimental group (given treatment), given a smart egg puzzle game every week twice for two weeks.
The population in this study were children of the B-TK Aisyiyah group who visited Surabaya with a total sample of 88 children. While the sampling technique used is cluster sampling. The independent variable in this study is a smart egg puzzle game while the dependent variable is the understanding of geometric concepts. The technique used to collect data is the test instrument that was given before the pre-test, and after the post-test, the clever egg puzzle game carried out in the experimental class. The instrument used to measure data on understanding geometric concepts is four items. Furthermore, the test instrument results from understanding geometric concepts in validation and reliability tests using the help of SPSS 25 Software for Windows.

The technique used to collect data in this study is observation and documentation. Then before hypothesis testing is carried out data normality test and data homogeneity, the test data is analyzed, to test the hypothesis the researcher uses a one-way ANOVA test with the help of SPSS 25 software for Windows.

Table 1. Quasy Experimental: Nonequivalent Control Group Design

\begin{tabular}{cccc}
\hline Group & Before & Treatment & After \\
\hline Experiment & $\mathrm{O}^{1}$ & $\mathrm{X}$ & $\mathrm{O}^{2}$ \\
\hline Control & $\mathrm{O}^{3}$ & - & $\mathrm{O}^{4}$ \\
\hline
\end{tabular}

\section{RESULTS AND DISCUSSION}

a. Based on the validation of the four items, the items tested were all valid

Table 2. Test the Validity of Understanding Geometry Concepts

\begin{tabular}{cccc}
\hline Item & Corrected item-Total Correlation $\left(r_{\text {hitung }}\right)$ & $r_{\text {table }}$ & Decision \\
\hline Item 1 & 0.772 & 0,3202 & Valid \\
\hline Item 2 & 0.398 & $0,3202-$ & Valid \\
\hline Item 3 & 0.780 & 0,3202 & Valid \\
\hline Item 4 & 0.591 & 0,3202 & Valid \\
\hline
\end{tabular}

Based on the Table 2 above, it can be interpreted that to test the validity of items, the variable understanding of geometric concepts can be seen from the correlation coefficient of the calculated value of each item. The calculated value of each item is then compared to rcount . rtable. of 0.3202 . Based on the validation test above, the value of item 1 (0.772), item 2 (0.398), item 3 (0.780), and item 4 (591) are obtained. This value is greater than the rtable value so that it can be concluded that the research instrument variable understanding of geometric concepts is valid.

\section{b. Test Reliability Understanding Geometry Concepts}

Reliability testing for understanding geometric concepts is based on Cronbach's Alpha (a) obtained with the help of SPSS 25 For Windows. The following are the results of calculating the reliability test for understanding geometric concepts: 
Table 3. Test for Reliability of Understanding of Geometry Concepts Reliability Statistics

\begin{tabular}{cc}
\hline Cronbach's Alpha & N of Items \\
\hline .809 & 4 \\
\hline
\end{tabular}

The value of Cronbach Alpha ( $\alpha$ ) from table 3 for the variable understanding of geometry concepts is 0.809 ; the value is more than 0.60 , it can be concluded that the research instrument variable understanding of geometric concepts is reliable.

c. Hypothesis test the effect of smart egg puzzle game on the understanding of geometric concepts of children aged 5-6 years TK Aisyiyah branch Ngagel.

In this hypothesis test, the data used are final observation data from the control and experimental groups. Then the final observation data is tested using a one-way ANOVA technique.

Table 4. ANOVA Test One Path of the First Hypothesis ANOVA

\begin{tabular}{cccccc}
\hline \multicolumn{6}{c}{ ANOVA } \\
\hline \multicolumn{6}{c}{ Understanding of geometric concepts } \\
\hline Sum of Squares & $\mathrm{df}$ & Mean Square & $\mathrm{F}$ & Sig. \\
\hline $\begin{array}{c}\text { Between } \\
\text { Groups }\end{array}$ & 168.158 & 1 & 168.158 & 21.41 & .000 \\
\hline Within Groups & 675.296 & 86 & 7.852 & & \\
\hline Total & 843.455 & 87 & & & \\
\hline
\end{tabular}

Based on table 4 above, the results of one-way ANOVA test are obtained to test the first hypothesis, namely the F-count value of 21,415 and the significance value of 000 , while the value of Ftable is 3.10 with a level of $5 \%$ or 0.05 . Fcount is greater than Ftable so that $\mathrm{HO}$ is rejected and accepts Ha1, which means that smart egg puzzle games significantly influence the understanding of the geometry concept of children aged 5-6 years TK Aisyiyah Ngagel Branch Surabaya.

In the research and hypothesis testing, proving that smart egg puzzle games significantly influence the understanding of geometric concepts. The implementation of this study was divided into two research groups, namely the control group and the experimental group. Both groups have the same or almost the same characteristics and properties. This is evidenced by the homogeneity test with the results for the geometric concept understanding variable is 0.206 , the value is greater than the significance of 0.05 so that the data from the understanding of geometry concept variables are homogeneous.

The experimental group was given treatments, namely the smart egg puzzle game, this game is played twice a week for two weeks. This smart egg puzzle game is carried out for 30-45 minutes when learning activities are carried out in a spacious room or school yard while the control group was not treated only following the scheduled learning by the teachers.
The research at the TK Aisyiyah Ngagel Surabaya branch used treatments in the form of a smart egg puzzle game. Smart egg puzzle games are carried out for 30-45 minutes when learning activities take place using work themes. This smart egg puzzle game is done in a spacious room or school yard. This clever egg puzzle game influences aspects of child development, this is in line with Clark's statement (2018) which states that by playing children become happy and can develop positive developments for cognitive, affective and sociocultural growth. This is by the principle of playing that children's abilities can be developed through play activities. Children learn with their experience.

The results of this study found that the average class score for understanding geometric concepts in the experimental class was higher, which was equal to 2.9 of the control group children, which was equal to 2.2 . This is because the experimental class received treatments in the form of a smart egg puzzle, while the control class did not get treatment.

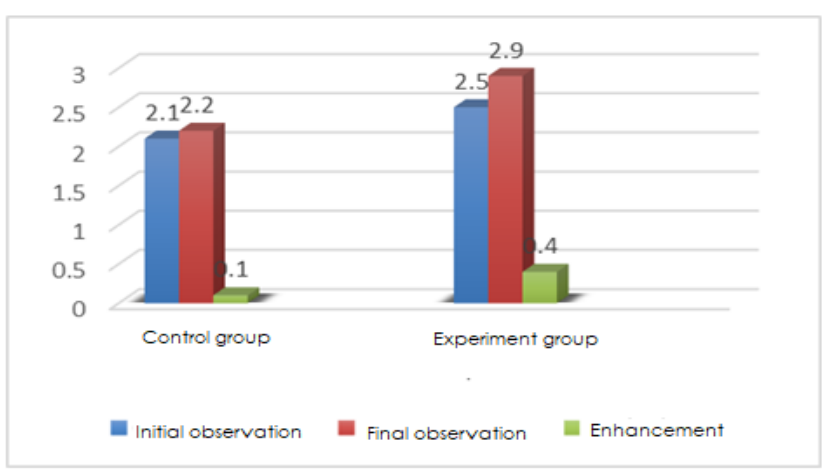

Figure. 1 comparison of scores obtained understanding geometric concepts initial and final observations of the control group and experiment

Based on graph 1, it can be concluded that the average value of understanding geometric concepts in the control group is at the initial observation and the final observation is 2 , which means that the children in understanding the geometric concepts are fairly developed categories. In the control group, the average initial observation increased by 0.1

While the average value of the group understanding of geometric concepts in the experimental group is at the initial observation of 2 and the final observation is 2.9 , which means that children in understanding geometric concepts including categories develop according to expectations. In the experimental group, the average initial and final observation groups increased by 0.4 . From the data above the average increase in the initial observation group and the final observation of the experimental group was greater than the control group. This is because the experimental group received treatment for the smart egg puzzle game.

Thus the application of smart egg puzzle games in children aged 5-6 years Aisyiyah Kindergarten Ngagel Surabaya Branch is very useful, especially in developing an understanding of geometric concepts. 


\section{CONCLUSION}

Smart egg puzzle game significantly influences the understanding of the geometry concept of children aged 5-6 years TK Aisyiyah, Ngagel Surabaya branch. One way ANOVA test proves that $\mathrm{HO}$ is rejected and accepts Ha1, which is known from the calculated $\mathrm{F}$ value of 21,415 greater than Ftable of 3.10. There are differences in the average value of understanding the geometric concepts of the experimental group, which is 0.4 greater than the control group at 0.1 .

\section{REFERENCES}

Ayu, S. (2014). Segudang Game Edukasi Mengajar, Macam-Macam Game untuk Mengajar. Yogyakarta: Diva Press

Beaty, J. (2013). Observasi Perkembangan Anak Usia Dini. Edisi Ketujuh. Jakarta: PT. Fajar Interpratama Mandiri

Clark, C. D. (2018). Play. Rutgers university, Camden, NJ, United States Reference module in neuroscience and biobehavioral psychology. doi:10.1016/B978-0-12-809324-5.21792-6

Creswell, J.W. (2013). Research design qualitative, quantitative, and mixed methods approaches. Sage Publications. Inc

Fernandez, C., Yomogida, M., Aratani, Y \& Hernandez, D. (2017). Dual food and energy hardship and associated child behavior. Academic pediatrics. doi:10.1016/j.acap.2018.07.002

Gita, D.Y. (2017). Pengaruh permainan puzzle terhadap perkembangan kognitif anak usia 5-6 tahun di TK negeri pembina Manyaran tahun ajaran 2016/2017.Naska Publikasih. (diakses 15 januari 2019)

Gozzi, R.Jr. (2014). The jigsaw puzzle as a metaphor for knowledge. United States: International Society for General Semantics.

Irene C.M., Giofrè D \& Caviola, S. (2017). Learning geometry: the development of geometrical concepts and the role of cognitive processes. Acquisition of complex arithmetic skills and higher-order mathematics concepts pages 221-246.

doi:10.1016/B978-0-12-805086-6.00010-2

Jackman, H.L. (2012). Early education curriculum: a child's connection to the world, fifth edition. Canada: Wadsworth, Cengage Learning,

Jannah, M. (2016). Psikologi eksperimen sebuah pengantar. Surabaya: UNESA University Press

Jeona, I., Buettnerb C. K., Granta, A \& Lang, S.N. (2018). Early childhood teachers' stress and children's social, emotional, and behavioral functioning. Journal of applied developmental psychology. doi:10.1016/j.appdev.2018.02.002

Joseph, F., Hair, Jr., William, C., Black Barry J,. Babin R.E,. Anderson. (2014). Multivariate data analysis seventh edition. Pearson Education Limited ISBN 10: 1-292-02190-X ISBN 13: 978-1-292-02190-4

Latif, M., Zukhairina. Zubaida, R., Afandi, M. (2013). Orientasi baru pendidikan anak usia dini teori dan aplikasi. Jakarta: Kencana Prenada Media Group

Lestari, K. (2011). Konsep matematika untuk anak usia dini. Jakarta : Departemen Pendidikan dan Kebudayaan Direktorat Jenderal Pendidikan Anak Usia Dini

Lucas, F.M.M. (2017). The game as an early childhood learning resource for intercultural education. Procedia-social and behavioral sciences. doi:10.1016/j.sbspro.2017.02.127

Mulyasa. (2014). Manajemen PAUD. Bandung: PT Remaja Rosdakarya

Mursid. (2016). Pengembangan pembelajaran PAUD. Bandung: PT Remaja Rosdakarya.

Pavlovicova, G \& Zahorska, J. (2015). The attitudes of students to the geometry and their concepts about square. Procedia-social and behavioral sciences. doi:10.1016/j.sbspro.2015.07.253
Peraturan Menteri Pendidikan dan Kebudayaan Republik Indonesia Nomor 137 Tahun 2014 tentang Standar Nasional Pendidikan Anak Usia Dini

Purwanto. (2012). Metodologi penelitian kuantitatif untuk psikologi dan pendidikan. Yogyakarta: Pustaka Pelajar Offset

Sari, Y.K. (2018). The effect of geometric puzzle game towards children's recognition of geometric shapes and fine motor. Advances in Social Science, Education and Humanities Research, volume 212

Schaik, J.E.V \& Hunnius, S. (2016). Little chameleons: The development of social mimicry during early childhood. Journal of experimental child psychology. doi:10.1016/j.jecp.2016.03.003

Stepletona, K., Boska, E.A, Jacquelynn, F., Durona., Greenfielda, B., Ocasioa, K., Michael J \& MacKenzie. (2018). Exploring associations between maternal adverse childhood experiences and child behavior. Children and Youth Services Review.

doi:10.1016/j.childyouth.2018.10.027

Sugiyono. (2016). Metode penelitian kuantitatif, kualitatif, dan R\&D. Bandung: Alfabeta,

Susanto, A. (2011). Perkembangan anak usia dini pengantar Padaberbagai aspeknya. Jakarta: Kencana Prenada Media Group.

Turney, K \& Lanahan, S. (2015). The academic consequences of early childhood problem behaviors. Social science research. doi:10.1016/j.ssresearch.2015.06.022

Yulianti, R. (2012). Permainan yang meningkatkan kecerdasan anak. Jakarta: Lancar Aksara. 